\title{
THE IRANIAN REVOLUTION
}

\author{
Dr. M. Vedat Gïrbüz \\ Kahramanmaraş Sütçü İmam Üniversitesi \\ Fen Edebiyat Fakültesi
}

\section{Özet}

İan Deurimi

İan Devrimi neden ve sonuçlanı açısından oldukça tartışmalıdır. Devrim dünyadaki diğer devrimlerin çoğuyła sebepleri açısından bir benzerlik gösterse de, sonuçları diğerlerinden farklı yönde gelişmiştir. İran devrimi yıkılan düzenin yerine modern bir politik sisıemi ikame cememişstir, ancak yeni bir idcolojiyi ve politik sistemi uygulama alanına sokmuştur. İan devriminin otantikliği, İan'm sahip olduğu kuiturel ve sosyal yapıdan ileri gelmektedir. İan devrimi her şeyden önce Şahın otoriter rejimine karşı girişilen bir darbe idi. Politik ve sosyal amiller, ekonomik yada sınıf mücadelesi temalarından çok daha güçliu olarak devrimi etkilentiştir.

Anahtar Kelimeler: Iran Devrimi. Rastakhiz. \$iilik, Scraiti. Humeyıi.

\section{Abstract}

The Iranian revolution is highly controversial in terms of both its causes and its results. Perhaps the causes of the revolution are similar to those of other revolutions, but the results are very different. The Iranian revolution did not end up formulating any modern political system. But it did spawn a new ideology and political structure. The authenticity of the Iranian revolution stemmed from Iranian culture and Iranian social structures. The Iranian revolution was a strike against the Shah's authoritarian regime. Political and social consequences were more effective in the revolution than any other economic force or class struggle.

Key Words: Iraniun Revolution, Rastakhiz, Shiism, Sharili. Khomeini. 


\section{The Iranian Revolution}

\section{INTRODUCTION}

The Iranian revolution is highly controversial in terms of both its causes and its results. The revolution is considered a genuine popular movement by almost all scholars. However, it is different from other modern revolutions, and it is also different from the peasant-based third-world-type revolutions. Perhaps the causes of the revolution are similar to those of other revolutions, but the results were very different. The Iranian revolution did not end up formulating any modern political system. But it did spawn a new ideology and political structure.

The authenticity of the Iranian revolution stemmed from Iranian culture and Iranian social structures. The culture shaped an Iranian style of politics, which was frequently disrupted by revolutions over the centuries. Shah Mohammed Reza, Khomeini and other leaders were products of Iranian culture and ruled the country in a quintessentially Iranian style. Although the Shah adhered to the tenets of Iranian political culture, he also pursued modernization. The Shah's modernization never brought flexibility to traditional rigid Iranian politics.

The Shah's modernization was a major threat to Iranian culture. Traditionally, Iranian political regimes seemed quite authoritarian. This rigid authority acted as the cohesion keeping society united. But the regime was immediatcly challenged by the silent society, which was generally loyal and obedient to the regime, whenever the regime was weakened. The Iranian revolution occurred when silent but dissatisfied social groups converged.

The religious motives vested all individuals in society and ultimately revived a modernized form of Islam. Religion seemed a perfect way for social groups to express their dissatisfaction against the regime. Ideological differences were temporarily ignored. There was a ceasing of the creation of a unique Islamic opposition to get rid of surviving political system. Recent 
Iranian president Khatami stated that Iran was always ruled by one authoritarian regime or another. The regime that emerged from the revolution was also authoritarian. And this authoritarianism served to unite society.

\section{THE NATURE OF THE REVOLUTION}

The Iranian revolution was a popular movement. According to Richard Cottam, it was one of the greatest populist explosions in human history (COTTAM, 1990: 3.). Assef Bayat wrote that the revolution attracted widespread popular support. A section of the bourgeoisie, notably the bazaar merchants; a range of urban classes; traditional and new petty-bourgeoisie; tradesmen; small producers and civil servants; and newly urbanized and proletarianized working classes all participated in the revolution (BAYAT, 1987: 77).

Although every segment of society took part in the revolution, peasant participation was surprisingly minimal. This fact makes it more difficult for scholars to explain the revolution. Even famous political scientists such as Theda Skocpol needed to make adjustments for interpreting the Iranian revolution according to her social revolution theory. Skocpol argues that the Iranian revolution was a social revolution, but it challenged the expectations of revolutionary causation that Skocpol theorized through comparative historical research on the French, Russian and Chinese revolutions (SKOCPOL, 1994: 240). Social revolutions, according to Skocpol, "are rapid, basic transformation of a country's state and class structures, and of its dominant ideology" (ibid). Because the Iranian revolution was mass-based and transformative of basic socio-cultural and socioeconomic relationships in Iran, "it surely fits more closely the pattern of the great historical, social revolutions than it does the rubric of simply a political revolution, where only governmental institutions are transformed" (SKOCPOL, 1994: 241).

In Skocpol's social revolution theory, social revolutions in thirdworld countries are not simply products of rapid modernization that lead to widespread social discontent and disorientation as many theorists suggested: "The mass, lower-class participants in revolution cannot turn discontent into effective political action without autonomous collective organization and resources to sustain their efforts" (ibid). Although she argued that social revolutions are not a product of rapid modernization, she admits that the Iranian revolution did stem from such modernization. 
She also challenged the idea that "revolutions are not made. They came." Skocpol said that that the Iranian revolution was made by a mass-based social movement, which aimed to overthrow the old order (SKOCPOL, 1994: 242).

Skocpol successfully formulates the emergence of leadership in social revolutions but fails, in the Iranian case, when she emphasizes the role of peasants in the revolutions:

Social revolutions have not becn caused by revolutionary movements in which an ideological leadership mobilizes mass support to overthrow an existing system in the name of a new alternative. Revolutionary leaderships have often been absent or politically marginal until after the collapse of pre-revolutionary regimes. And popular groups, especially peasants, have contributed to a revolutionary transformation by revolting for concrete ideals and goals separate from those espoused by the revolutionary leadership that end up consolidating revolutions by building up new state organizations (Skocpol, 1994: 241).

Skocpol reaches a concrete conclusion about the nature of the Iranian revolution:

In Iran, the revolution was made but not by any modern revolutionary parties, not by the Islamic guerillas, or by Marxist guerillas, or by the communist (Tudeh) Party, or by the secular-liberal National Front. Instead it was made through a set of cultural and organizational forms thoroughly socially embedded in the urban communal enclaves that became the centers of popular resistance to the Shah (SKOCPOL, 1994: 250).

Although Skocpol does not possess insightful research about the Iranian revolution, she systematizes the revolution by using her scholarly understanding and making outlines.

Skocpol's theory proves useful as a foundation for an explanation of the Iranian revolution's socio-cultural character.

\section{The Iranian Revolution Against Rapid Modernization:}

Almost every single source emphasizes that Iranian revolution primarily was against rapid modernization. The term 'modernization' is a very large concept, one around which it is very difficult to draw concrete boundaries. Where does modernization start and stop? Is modernization always synonymous 
with westernization, or is modernization a separate phenomenon from westernization? Obviously industrialization and economic development are crucial components of modernization, and it is also natural for modernized societies to undergo cultural, social, and political changes, and these changes manifest themselves quite differently in each country, reflecting the particulars of the societies going through the modernization process.

In the Iranian case, it was not modernization pursued by the Shah but a deviant type of modernization. Authoritarian regimes are incapable of modernizing societies. Although it is true that many authoritarian regimes started the modernization process, they succeeded in their modernization attempts only when they democratized. Iran was relatively successful in developing its economy, and it was in some respects successful in forming highly modernized intellectual groups. This success created a social dichotomy. Moreover, the intellectuals were alienated by the Shah's undemocratic political decisions.

Japan succeeded in modernizing its economy under authoritarian regimes, but this modernization was effected through the efforts of individuals rather than the decrees of the government. In Soviet Russia, economy and society were modernized by an authoritarian regime. But, of course, the regime eventually failed. In Iran, the Shah himself undertook the modernization of economy and society. But the Shah had a limited and distorted understanding of modernization's essential components.

Modernization could be achieved only by technocrats, experts, intellectuals, scientists, and scholars in a free environment constructed by political authorities

A general look at the Shah's modernization of the economy, politics, and society will give us a broader understanding of my thesis on the problems of his modernization policies. Although the modernization procedure did not start with Mohammed Reza Shah, my gaze will be trained on his regime.

\section{Economic Modernization}

Although its plans were ambitious, Iran's economic growth, which began in the 1970s, was actually ephemeral. The Iranian economy was primarily based on oil. By 1973, Iran gained full control over its oil industry. Oil income composed accounted for 84 percent of Iran's total revenues (MILANI, 1988: 162). The growth of industry sped up following the quadrupling of oil revenues in 1973 and 1974 (AMJAD, 1989: 31). thanks to the oil crisis of 1973. During the period of 1973 to 1977 , Iran's GDP grew by an average annual rate of 8.4 
percent at constant price (AMUZEGAR, 1991: 58). Between the years 1973 and 1976, Iran's per capita income reached a Third World record of $\$ 2000$ (BENARD / KHALILZAD, 1984: 12). Quickly-growing oil revenues resulted in the Shah developing more-ambitious industrialization programs. The budget of the Fifth Plan, 1974 to 1978 , was doubled overnight, from $\$ 60$ billion to $\$ 120$ billion. The Shah dreamed of transforming Iran into the fifth most industrialized nation in the world, in less than twenty years (AMJAD, 1989: 31).

The Shah made the grave mistake of promising too much and delivering too little. The results of rapid industrialization--without taking into account low productivity, a lack of skilled personnel, shortages of port facilities and other shortcomings--were disastrous. The Shah's ambitious industrialization plans drained the treasury. The Shah amateurishly turned the oil bonanza into a terrible industrialization failure. Although in 1974, Iran had a $\$ 2$ billion surplus in its budget, the 1978 budget ended up with a $\$ 7.3$ billion deficit.

The Shah's badly executed industrialization programs increased Iran's dependence on imports and foreign trade. The growth of imports and the increasing dependence of foreign industries deeply weakened Iran's industry and traditional merchant class (the Bazaaris). Rich Iranians preferred to invest their money abroad and avoided investing in Iran because of the nation's unstable economic and political conditions. Princess Ashraf commented on a $\mathrm{BBC}$ radio program that "there are foreigners who saw that Iran in ten years time would be another Japan. They could not afford another Japan in Asia" (AMUZEGAR, 1991: 85). This statement supports a conspiracy theory, arguing that foreign intrigue caused the Iranian revolution. The Princess envisioned Iran as prospering but side-tracked because of the Revolution. The Princess' words and deeds did not always coincide, because the royal family invested some $\$ 30$ to $\$ 72$ billion (AMUZEGAR, 1991: 75). abroad, thereby avoiding investing in Iran, which was supposed to emerge as the fifth most industrialized nation.

The Shah's economic modernization was partly successful, but it eventually crumbled. One may assume that economic modernization in Iran was not challenged by the people, but economic instability and economic gaps between the classes were challenged. Although some scholars believe that economic hardship after 1975 was a crucial reason for the Iranian revolution, I do not think that economic reasons were that important because the state of Iran's economy was not so awful that it warranted revolt. Political and social causes had far more impact on the revolution. 


\section{Political Modernization}

The Shah essentially left political modernization to the wayside while he tried to modernize the economy and society. While Iran underwent economic and social transformations, a parallel political transformation never took place. The authoritarian regime in Iran did not permit the exercise of the democratic process even though the nation was ostensibly a constitutional monarchy. In reality it functioned more as a dictatorial monarchy.

After the 1953 coup, the Shah adamantly persecuted his opponents and restricted political freedom. M. Salehi argues that because of the "police state's" repression, opposition was forced underground and, therefore, became radicalized (SALEHI, 1988: 10).

Although the Shah made numerous references to the desirability of both democracy and free elections, he did not attempt to actualize either. Indeed, he actively worked against the establishment of democracy. In 1958, the Shah had introduced a parliamentary system in Iran, which was participated in by two political parties, but, in 1975, the Shah adopted the one party system, thereby creating the Rastakhiz (Resurgence) Party overnight. The Shah used the Rastakhiz as a tool to carry out his policies and to create a single-party political system loyal only to him. Party members enjoyed many opportunities. Those opposed to the party were seen as traitors. In the Shah's simple-mindedness, "those who are not with us are against us" (MILANI, 1988: 124). The Shah went too far and arrogantly declared that:

The place of those who oppose the Constitution, the monarchial system and the People-Shah Revolution is either in jail or outside Iran. Those who do not wish to enter into this political organization (the Rastakhiz) have two alternatives: They either belong to an illegal political party, like the Tudeh, in which case they should be jailed...(Milani, 1988: 124).

The Rastakhiz Party exerted another type of political pressure on society and fostered political corruption. Mohsen Milani states that before the formation of the Rastakhiz, some intellectuals had been bribed, but after its formation, the entire nation was bribed (MILANI, 1988: 124).

The biggest political problems for intellectuals and individuals were the prohibition of self-expression and a lack of political participation in the regime. The following is an explanation offered by an Iranian intellectual:

The great problem is lack of freedom. We have lots of intellectuals and technocrats who have views but they are never allowed to express them. Everything is dictated from the top. We have an intelligentsia but 
they have no chance to participate. They are supposed to support the regime. They do not like slavishly supporting the Shah, so, they turn against $\operatorname{him}(\mathrm{ZABIH}, 1979: 17)$.

According to Jerrold Green, the crisis of political participation was transformed into popular revolution. Political dissatisfaction created an increasing political polarity. Simultaneously, large numbers of once-passive Iranians were politicized into anti-regime sentiments and revolutionary behaviors (GREEN, 1982: 115).

The regime crated a reign of terror for those who did not support the party and the Shah. Tens of thousands of people were jailed and tortured by police force SAVAK in order to protect the regime. Iran gained a very bad reputation in human right issues. The Shah's strict political persecutions deepened the people's resentments against the regime. When the Shah's antiprofiteering campaign imprisoned thousands of merchants and closed thousands of businesses, resentment turned into strong hatred of the regime, and this hatred ignited the revolution.

The Shah's policy of political repression was the most important reason for the emergence of the Iranian revolution. Various revolutionary groups in Iran stood together under the banner of Islam, displaying the power of unity against the oppressive regime. If the Shah had loosened his iron grip on the society and if he had granted and promoted political freedom for people in a democratic environ, there is no doubt that the problems in Iran would have been resolved in a non-revolutionary manner.

\section{Social Modernization}

The Pahlawi dynasty launched reform after reform in an attempt to modernize the society. The general aim of these reforms was to create an educated, secular and westernized Iranian society. Because of the social reforms and industrialization, traditional Iranian society was destroyed, but, this new type of society, which was envisioned by Reza and Mohammed Reza Shahs, could not replace the old one because of the reforms' inadequacy. So, modernization of the society created a dichotomy. New and old types of unfriendly societies developed their causes to take the leadership in society. A modernized part of society supported by the government but a lack of political freedom made this group dependent on and a defender of the regime. Many of the modernized intellectuals, though, did not share the ideologies of the government. The autocratic regime of Iran decreased the effectiveness of the modernized groups in society. However, this traditional society--religious in nature--modernized itself in order to gain a substantial role in the society. 
Mohammed Reza Shah targeted the clergy in his social modernization. Iran could have a secular society if the influence of the clergy were eliminated or reduced. The Shah proposed a land regime in the White Revolution of 1963. The mullahs were aware that land reform and the modernization of society would result in the secularization of society and the reduction of their influence and power. Ayatollah Khomeini bitterly criticized the Shah's programs. Khomeini threatened that if the Shah continued his anti-Islamic activities, he (Khomeini) would ask the people to expel the Shah (AMJAD, 1989: 41). The Shah tried to modernize the clergy and create a type of cleric friendly him, a type that would establish a version of Islam supportive of the regime. For this reason the Shah ordered the creation of the controversial Sepah-e Din (Religious Corps) in 1971. The corpsmen were chosen from Islamic Studies graduates of different universities, and they were sent to various part of the country in order to propagandize (MILANI, 1988: 118).

The Shah's social modernization program aimed to reduce the impact of religion on society, and he also pursued a program that aimed to revitalize the ancient Iranian culture. This program imported many values from ancient Iranian culture into contemporary society. The Shah replaced the existing calendar with a new, historical one. In 1971 he organized the celebrations of the 2500th anniversary of the establishment of the Iranian dynasty with great fanfare, and he established new holidays derived from the ancient history of Iran. Despite the Shah's efforts, the grassroots Islamic culture of Iran still remained powerful. The modernization of Islam by some intellectuals free from the state strengthened the traditional culture.

Jahangir Amuzegar emphasizes the importance of the traditional culture of the Iranians as an extremely vital factor for the survival of 'Iranian-ness.' According to Amuzegar, without Iran's traditional culture preserved, Iranian identity during the centuries against the internal dangers and the dangers of foreign invaders would have been destroyed. Stripping Iranian traditional culture from the society meant destroying Iranian identity and that a new kind of cultural identity would be insufficient. A reading of Amuzegar's cultural analysis of the Iranians elucidates the social dynamics of the Iranian revolution that were most essential to the revolution. A lack of understanding about Iranian culture and society surprised scholars and the entire world.

According to Amugezar, because of the differences in ethnic and tribal background, the concept of an Iranian national identity is less persuasive, but Iranian culture is directly recognizable. The Iranians are always ready to accept order and authority in a pragmatic way: 
Iranians fear and even respect power if they must, but in their hearts they root for underdog. Their passionate, poetic, artistic and mystical sprit tents to bridge the gap between their own spiritual heritage and new Western materialism and rationality. Due to the strength and attractiveness of their culture, they have a unique ability to turn defeat into victory making foreign invaders accept their mores, values, and way of life (AMUZEGAR, 1991: 100).

According to Amuzegar's cultural analysis, for the Iranians, life is a gamble and all tricks are free. "At it's zenith, the talent develops into the techniques of conspiracy intrigue and complots, of which Iran's recent history is replete" (AMUZEGAR, 1991: 103). Iran's traditional culture resisted changes, and Iranian culture characterized Iranian politics before and after the revolution. However, the Pahlawis tried to transform the culture. Iranian individuals enjoy establishing their authorities parallel to their cultures. Iranian leaders also have the same tendency. According to Amuzegar, Iran's four major leaders in the $20^{\text {th }}$ century--Reza Shah, Mosaddeq, Mohammed Reza Shah, and Khomeini-greatly resemble each other. All four leaders shared the same manifestations of 'ambition, arrogance, authoritarianism, inflexibility, and demagogy. They all craved adulation and unchallenged power. All four believed in the absolutes: there was either good or evil, right or wrong, friend or enemy, patriot or traitor, and nothing in between' (AMUZEGAR, 1991: 111).

When the government forced the society to change, defenders of the traditional and religious cultures also tended to modernize the traditional culture to cope with the realities of the modern world. The most important figure in the modernization of the traditional culture was Jalal Al-e Ahmad. He attacked the rapid westernization, and he began to bring the Iranian past and the future together in terms of culture (MACKEY, 1998: 215).

Efforts to modernize the religious culture mostly came from prominent non-clerical intellectuals. Ali Shariti, Mehdi Bazargan and, to a lesser degree, Jala Al-e Ahmad, were (MILANI, 1988: 139) well-known modernist intellectuals. They all shared the conviction that in Shiitism one must find all the ingredients of progressive and modern ideology capable of neutralizing the cultural hegemony of the West in Iran, ending the alienation of educated Iranians from their native culture. The central theme for all three was a return to Iran's indigenous Shiite culture.

Ali Shariti deeply affected Iranian youth and intellectuals with his revolutionary ideas, which were formulated using scientific and sociological methods. Shariati blamed the clergy for betraying Islam itself. He said that the vital task of understanding the Koran and the Hadith, and revealing the revolutionary meaning of true Islam, now fell upon the shoulders of the 
intelligentsia (ABRAHAMIAN, 1989: 113). Shariti sought to lay the ideological foundation for the creation of a new nation-state in Iran on the basis of Islam as a political ideology counter to the attempts of the secular intelligentsia. Despite his call for a return to early Islam, he did not seek to bring the society back to the first Islamic century. According to Shariti, Islam existed to provide the ideals and values for establishing a new order (BASHIRIYEH, 1982: 70).

The Modernization of Iran's Islamic culture easily opened the gates for the flow of political, revolutionary understanding of the religion since Shiism was highly politicized in the past and its political legacy was continuing because of the expectance of the last Imam, who could appcar on the earth in any given moment. When the Eleventh Imam died without having a son, a serious crisis occurred. It was solved by the doctrine of occultation, (ARJOMAND, 1984: 36) which said that the rightful Imam went into hiding and would later return to the world.

Members of the early Iranian intelligentsia were anti-tradition and anticlerical. By contrast, the young intelligentsia of the 1970s turned to Islam and presented it as a revolutionary ideology. The main features of this new ideology were hostility to the West and an emphasis placed on the local economy and culture (BASHIRIYEH, 1982: 70). The secular segment of the society was alienated by the government because of its unwillingness to share political power and because of the violation of basic human rights (KAMAL, 1988: 233).

Resistance against the Shah's social modernization by traditional groups and the reformulation of the traditional culture and politicization of Islam by traditional groups influenced every segment of Iranian society. Rediscovery of traditional culture and Islam found outlets in the spread to the nation when the Bazaari embraced the emerging fashion of traditional culture. The success of the modernized traditional culture in Iranian society and the support of traditional culture by the alienated secular and national intelligentsia created a consensus among different segments of the society, and a temporary alliance between these groups made possible the Iranian revolution.

\section{The Iranian Revolution is a Social Revolution and the Revolution was Made by a Mass-Based Social Movement}

There is no doubt that the Iranian revolution a social revolution. Every segment of society took part in the revolution. The Iranian revolution was staged primarily by social groups. Islamic leadership appeared only later on. The Shah's wrong-headed policies affected of all society and created strong 
opposition to the regime. A small group did support the Shah, but members of this group were largely ineffective in society.

The popular uprising in Iran was interpreted by many as a rejection of modernity (BENARD/KAHLILZAD, 1984: 13) because modernization endangered the existence of Iran's traditional culture and social structure. According to Amuzegar, the fall of the Shah was a clash between Western modernization and traditional, religious, economic and social structures. The Shah's human rights violations--committed for the sake of his modernization policies-- created a popular hatred of both the Shah's policies and modernization itself. Therefore, Iranians turned towards the alternative, negative view of modernization offered by Khomeini's camp. Because the Shah applied Westernization recklessly, the reaction was naturally violent (AMUZEGAR, 1991: 37). The revolution in Iran did not take place because of a sudden, dramatic Islamic resurgence, but mainly as a result of deteriorating socio-economic conditions and political repression that became intolerable as soon as the masses realized that it was possible to avoid them (AMUZEGAR, 1991: 53).

The high degree of political polarization against the Shah's suppressive policies provided the revolution its dynamic and culminated in countermobilization. In fact, the Iranian socio-political climate has historically been receptive to nurturing extremist and revolutionary ideologies. Most of the revolutionary leaders had been associated with the regime of Mosaddiq, and they viewed the revolution as a continuation of Mosaddiq's movement (COTTAM, 1990: 4).

The revolution in Iran was prepared by mostly urban social classes. The participation of different political groups such as nationalists, seculars, Marxists and religious groups, distinguished the Iranian revolution from other Third World revolutions. A high degree of participation from all social sectors formed the revolution, which was highly organized and successful.

In the revolution, Bazariis played a crucial role. When the Bazariis were extremely successful in carrying out Islamic propaganda in society, a different type of Iranian intellectuals supported the emerging revolutionary causes because they believed that the Shah's regime should be ousted first. Many difficulties hindered the Iranian secular and nationalist intellectuals in their quest to attract the people's attention to their ideologies. Although there were large numbers of Iranian intellectuals and western educated individuals, ordinary people did not support these intellectuals fully. Interestingly, the secular and nationalist elite were also aware of their national culture. They were not willing to let western culture destroy their values. Obviously, Islam was one 
of the most important Iranian cultural dynamics. While the elite wanted Iranian culture foremost, they also had to accept the importance of the Islamic values, and they did so. The success of the revolutionary Islamic modernists and their increasing popularity in society resulted in a variety of intellectuals unconditionally supporting the religious revolutionaries.

Liberal intellectuals insisted that once the Pahlawi regime was ousted, Iran would have a democratic system. The Liberal intellectuals easily became a mouthpiece for the revolutionary interests rather than an analyst of the characteristic of the revolution (AFKHAMI, 1985: 176). Demonstrations in 1978 strengthened the connection between the secular and the religious forces within the opposition, and at the same time aided Khomeini and his followers in establishing hegemony over the rest of the opposition. The secular groups, including the Left, by and large accepted and used religious tactics to mobilize the people against the Shah (MOADDEL, 1993: 158). The Left, as a whole, underestimated the strength of a populist movement increasingly under clerical control (COTTAM, 1990: 7).

Secular women, while participating in street demonstrations, should wear the veil as a symbol of resistance to the Shah's Westernization policies. Highly educated women who had proudly worn the veil for the sake of the revolution, probably had no idea what would happen in the post-revolutionary Iran about women's liberty (MOADDEL, 1993: 159).

The working class participated in the revolutionary movements at a rather late time. In the summer of 1978, workers actively participated in the demonstrations, and they started mass strikes. In terms of militancy, workers lagged behind the other urban groups and professionals (BAYAT, 1987: 77-79).

\section{Absence of Political Leadership until the Success of the Revolution:}

Skocpol's political revolutionary theory is partly applicable to the Iranian revolution. However, there were important numbers of non-religious participants in the revolution, and they aimed at establishing systems very different from an Islamic Republic. But the wide-spread revolutionary movements were made by religious groups or their supporters. Before the success of the revolution, it was not surprising that the religious groups would take the leadership in post-revolutionary Iran. Unlike the revolutionaries in Russia and China, the Iranian revolutionaries did not fight against each other. Rather, they consolidated their power in order to facilitate the deposition of the 
Shah and ensure that the establishment of the Islamic Republic was not seriously challenged.

Shiite revolutionary discourse transformed the political, social, and economic discontents of the $1970 \mathrm{~s}$ into a crisis. A large network of approximately 80,000 mosques and holy shrines served about 180,000 mullahs, facilitating the distribution of revolutionary Islamic propaganda (ZABIH, 1979: 20). Bazaaris were also a crucial component in revolutionary religious propaganda. They were the traditional allies of the mullahs for the centuries. Mullahs educated bazariis' children. In turn, the bazaari financially supported the mullahs. Because of their conservative character and importance in the society, the bazaari could instantly mobilize the masses for revolutionary purposes. Bazaaris were against the Shah's westernization policies, and they were economically weakened because of the Shah's programs, which unleashed an enormous volume of imports. These imports destroyed domestic production and the merchant class.

When the Anti-Profiteering Campaign was launched in 1974 by the Shah, the Bazaaris were very much alienated from the regime, and they organized demonstrations. Approximately 10,000 people were recruited from different parts of society: students, teachers, and housewives were unleashed upon the bazaars, with the right to hand out punishments ranging from prison sentences and deportations to business closures. Ten months after the beginning of the campaign, courts shut down or fined 250,000 businesses in Tehran alone and jailed thousands of merchants (ZABIH, 1979: 31).

The bazaari supported revolutionary religious policies, and they influenced the masses. Newly urbanized Iranians especially were highly affected by religious propaganda. Because of the industrialization and the destruction of village communal life, millions of peasants poured into the cities in order to search for jobs and better living conditions. In 1976, over 33 percent of Tehran's population had been born outside of that city (MILANI, 1988: 120). They lived in poverty in the ghettos. They were conservative and easily influenced by religious propaganda.

The political ideology of the establishment of the Islamic Republic, ruled by the clergy, was considered Khomeini's invention. This ideology was incompatible with the traditionally accepted interpretations of Shiite Islam by opposed clergy (HOOGLUND, 1986: 81). Khomeini was not the architect of the revolution, but he became primarily a symbol for it after January 1978 and an active leader after September 1978 (AMUZEGAR, 1991: 30). So, six months before the conclusion of the revolution, Khomeini and his religious ideologies began to control the revolutionary forces. Thus, millions of Iranians flocked to 
the call of Khomeini (GREEN, 1982: 123). According to Amuzegar, the Islamic faction triumphed because it had more historical revolutionary dynamics than others did (AMUZEGAR, 1991: 36).

In conclusion, the Iranian revolution was a strike against the Shah's authoritarian regime. Political and social consequences were more effective in the revolution than any other economic force or class struggle. The revolution was a social one, and every sector of the society more or less supported it. The regime was inherently weak; the lack of staunch supporters in socicty and the Iranian army's ineffectiveness in the suppression of the revolution resulted in the elaboration of the regime at a surprisingly fast speed. The revolution was supported by a variety of Iranian intellectuals, but religious intellectuals took the leadership largely because of their popularity in society. The religious groups were not well enough prepared to take over the regime and establish their own, but desperate revolutionaries pushed fundamental Islam forward to rule the country.

\section{References}

ABRAHAMIAN, Ervand (1989), Radical Islam, The Iranian Mojahedin (London: I.B. Tauris Publishers).

AFKHAMI, Gholam R. (1985), The Iranian Revolution: Thanatos on a National Scale (Washington DC: The Middle East Institute).

AMJAD, Mohammed (1989), Iron From Royal Dictatorship to Theocracy (New York, Westport, London: Greenwood Press).

AMUZEGAR, Jahangir (1991), The Dynamics of the Iranian Revolution (New York: The State University of New York Press).

ARJOMAND, Said Amir, The Shodow of God and the Hidden Imam (Chicago, London: The University of Chicago Press).

BASHIRIYEH, Hossein (1982), The State and Revolution in Iran 1962-1982 (New York: St. Martin's Press).

BAYAT, Assef (1987), Workers and Revolution in Iran (New York, London: Zed Books).

BENARD, Cherly / KHALILZAD, Zalmay (1984), The Government of God, Iran's Islamic Republic (New York: Columbia University Press).

COTTAM, Richard (1990), "Inside Revolutionary Iran," RAMAZANI, R.K. (ed.), Iran's Revolution (Bloomington: Indiana University Press).

GREEN, Jerrold D. (1982), Revolution in Iran (New York: Praeger Publishers).

HOOGLUND, Eric (1986), Social Origins of the Revolutionary Clergy (Syracuse University Press) (ed. KEDDIE, Nikki R. / HOOGLUND, Eric). 
KAMAL, Youssefi (1988), The Alliance of Social Forces in the Iranian Revolution (New York: Ph.D. Dissertation at Fordham University).

MACKEY, Sandra (1998), The Iranians (New York: Penguin Group).

MILANI, Mohsen M. (1988), The Making of Iran's Islamic Revolution: From Monarchy to Islamic Republic (London: Westview Press).

MOADDEL, Mansoor (1993), Class, Politics, and Ideology in the Iranian Revolution (New York: Columbia University Press).

SALEHI, M.M., Insurgency Through Culture and Religion, the Islamic Revolution of Iran (New York, London: Praeger).

SKOCPOL, Theda (1994), Social Revolutions in the Modern World (New York: Cambridge University Press).

ZABIH, Sepehr (1979), Iran's Revolutionary Upheaval (San Francisco: Alchemy Books). 